
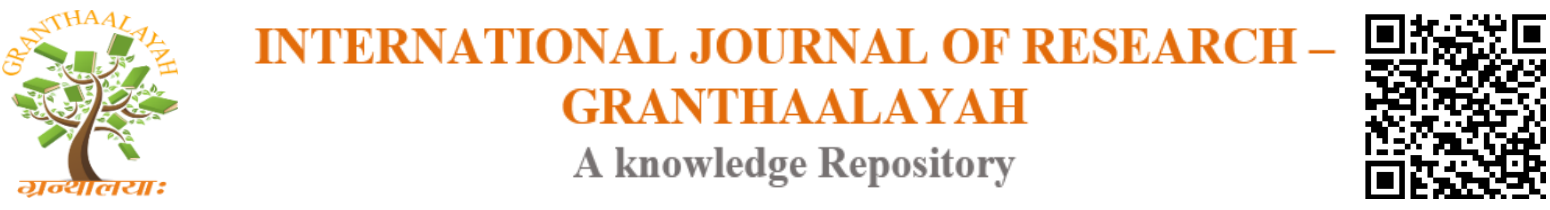

Social

\title{
IMPROVING STUDENTS' WRITING DESCRIPTIVE TEXT USING MIND MAPPING TEACHING STRATEGY OF THE TENTH GRADE STUDENTS OF SMA NEGERI 4 KUPANG IN ACADEMIC YEAR 2017/2018
}

\author{
Frangelina Pajolia Salem *1 \\ ${ }^{*}$ Graduate English Education of Nusa Cendana University, Kupang, Indonesia
}

\begin{abstract}
This project entitled "Improving students' writing descriptive text using mind mapping teaching strategy of the tenth grade students of SMA Negeri 4 Kupang in academic year 2017/2018." This research is aimed at; 1 ) to find out the use of mind mapping teaching strategy can improve the writing ability of tenth grade students, 2) to find out the weakness and strength of mind mapping teaching strategy. This research was classified as action research. It was done in two cycles. The first cycle was divided into two meetings and the second cycle was divided into two meetings. The research was done with the participation of 43 students of the tenth grade students of science program. The data obtained during the research were qualitative and quantitative data. The qualitative data were in the form observation checklist while the quantitative data were in the form of the students' scores.

The results of the research showed that the use of mind mapping effectively improved the students writing ability. Based on the qualitative data, the students were able to generate their ideas to produce well-organized recount texts. They were also able to use the appropriate vocabulary, correct grammar, punctuation, spelling, and capitalization in their writings. During the teaching and learning process, they also showed positive response toward the lesson. Based on the quantitative data, the students' mean score improved. In the pre-test, the students' mean score was 60.58 The students' mean score in the post-test 1 is 70.81 and the students' mean score in the post-test 2 is 78.60, which the last mean score is higher than KKM which is 75.00. It means that there are a difference between the students' writing descriptive text before and after the action research.
\end{abstract}

Keywords: Mind Mapping; Teaching Strategy; Descriptive Text.

Cite This Article: Frangelina Pajolia Salem. (2017). "IMPROVING STUDENTS' WRITING DESCRIPTIVE TEXT USING MIND MAPPING TEACHING STRATEGY OF THE TENTH GRADE STUDENTS OF SMA NEGERI 4 KUPANG IN ACADEMIC YEAR 2017/2018." International Journal of Research - Granthaalayah, 5(12), 147-154. https:// doi.org/10.29121/granthaalayah.v5.112.2017.485. 


\section{Introduction}

English has four basic language skills, namely listening, speaking, reading and writing. Receptive skills are listening and reading, while a productive skill covers writing and speaking. According to Harmer (2001: 199), "receptive skills are the ways in which the people extract meaning from the discourse they see or hear". It is also called receptive skill because students passively receive (listen and read) information and process it. Productive skills are more complex and difficult to learn.

Those four language skills are integrated each other, as Tans (2014: 1) in his book Writing an introduction stated that, "despite their differences, the skills are closely interrelated". Those who are good at speaking must also be good at listening vice versa. Those who are good at reading could also be good at writing vice versa. By mastering these skills students will be able to communicate in English well.

Among these skills, writing is a skill in learning language that must be mastered by everyone especially for students because writing is a final product after learners have studied about listening, speaking and reading. In writing, students apply what they hear, speak and read. According Harmer (2004: 31), he argues that writing is used for a variety of purposes in some different forms. Another argues, Byrne (1993: 1) stated that when students write they use graphic symbols: that is letters or combinations of letters which relate to the sound and they make when students speak. It can be conclude that students apply such combination of letters in writing process related to sounds as they are speaking.

In formal education, writing is taught from elementary up to university level. In senior high school writing is taught integrated with listening, speaking, and reading skills to achieve the goal communicative competence. This statement is supported by MGMP Sukoharjo, (2006: 14) in Pramusinta (2010 : 1) who asserted that, "writing is intended to be taught at senior high schools for the purpose of giving students discourse competencies to participate in creating text for accessing knowledge. At senior high school, writing skills are taught to help students comprehend creating texts by their own words, furthermore students are expected be able to make differences of types of genre text, such as report text, narrative text, descriptive text, and recount text.

The objective of writing is to produce a kind of writing text. Based on Curriculum 13 or K-13, students in senior high school have to be able to not only understand the nature of writing but also to produce certain various short functional texts, monologues and essays in the form of procedure, narrative, descriptive, recount and report text. Moreover, writing can facilitate students for better learning English.

Many English as a foreign language (EFL) students fail to be effective writer because they lack knowledge of vocabulary and appropriate writing strategy. The writer believes that teaching proper writing strategy can help second language learners overcome their writing problems. Effective writing strategy "provide the means to tackle complex problems in more efficient ways" (McNamara 2009: 34). One effective strategy is concept mind mapping, which is the use of visual tools to help readers understand material by transferring "the written content into concrete images" (Liu, Chen, and Chang 2010: 442). Through concept mind mapping activities, 
leaners connect previously learned and newly learned ideas into a visual representation, or "map".

A mind mapping is a diagram used to represent words, ideas, tasks, or other items linked to and arranged around a central key word or idea. It helps students to collect their ideas and the words to write the recount text (Buzan, 2005:6). Mind mapping can make students be more creative, because they can imagine their idea not only by writing the keywords but also by drawing the images in their minds.

Mind-mapping can help to make a new atmosphere in writing class. By using mind mapping, learning activity will be more interesting for the students (Widura, 2008). It can eliminate student's boredom because they can draw images on their minds and use many colors in making a draft before they write the text. They can also make a chronological text because they have to make their draft before they write. This strategy can make students be more active during the class and can improve students ability in writing.

Based on the writer preliminary research, the writer found several empirical problems in the teaching and learning process in writing class. Firstly, when the teacher asked them to write descriptive texts for several meetings in the writing class, most of them did not understand the structures of descriptive texts (lexicon grammatical and generic structures). The students found problems in order to organize their ideas to describe person, thing, or place that is asked by the teacher as their writing task.

Furthermore, the students still use the conventional strategy in prewriting activities; some of them also absolutely spend a lot of time to look up words in dictionary because they have lack of vocabulary in developing their idea. Moreover, they seem to find the difficulties in developing their ideas. In other words, they have difficulties in expressing ideas to be written. Then, the students also got problems in organizing their ideas, in terms of cohesion, coherence and unity in writing. It seems that it derives from the fact that they do not use the prewriting techniques to express their ideas before the real writing takes place. It can be concluded that they do not know how to develop their idea to be a good text. The last problem is the teacher seldom uses technique when teaching writing. After explaining the material, the students try to do the task on the worksheet or guidance book. The teacher asks the students to analyze the generic structure of the text and in the end the students make recount text based on their experiences. Of course, the students get bored with this teaching learning process. Eventually, the strategy is important to explore the students' imagination to make a good composition of writing. The researcher focuses on two problems. The first problem is to find out the use of mind mapping can improve the students writing skill of descriptive text. The second problem is to find out the weakness and strengh of mind mapping teaching strategy.

\section{Methodology}

This study is Classroom Action Research. It was conducted at SMA Negeri 4 Kupang which is located at Adisucipto street, penfui. The research was done with the participation of 43 students of the tenth grade students of science program. This study was conducted into two cycles. Each cycle consisted of several stages of Classroom Action Research procedure namely; planning, 
acting, observing, and reflecting. In planning, the researcher prepared lesson plans, teaching materials, and teaching media to be taught to the students. In acting, the researcher implemented the lesson plans using Mind Mapping teaching strategy in writing class. In observing, the researcher observed the weaknesses and strengths during teaching and learning process using mind mapping teaching startegy. In the last step of reflection, the researcher evaluated the use of mind mapping teaching strategy in writing class to improve students' writing descriptive text. This research used a mixed method between quantitative and qualitative research. The quantitative research was used to find out whether or not the use of mind mapping can help students improve their writing ability. The effects of the treatment were obtained from the difference between the pretest and posttest score. Moreover, this study used qualitative descriptive research by using observation checklist to describe students' responses toward this teaching strategy.

\section{Results and Discussions}

This part presented the qualitative and quantitative data gathered during the research that had been conducting in Cycle I with twomeetings and Cycle II with two meetings. Qualitative are the general finding of the research. The researcher used the interviews with the English teacher, the collaborator and the students involved during the teaching learning process. He also had done the observation and enclosed the checklist in each meeting conducted. To strengthen the data, the researcher used quantitative data to support the findings. Those were worthy enough to be used as evidences of students' improvement in writing descriptive texts through mind mapping after conducting the research. The scoring which was done by the researcher and the collaborator were based on the scoring rubric of Jacobs et al. Therefore, the tables below would present the mean scores of each aspect gained from the pre-test, the post-test of Cycle I and Cycle II.

\subsection{Cycle I}

Based on the rubric, in Cycle I, the students have improved a bit in terms of five aspects. Firstly dealing with the content, the students were able to enhance their writing and to make it relevant to the topic although a few students still find it difficult. They started to get the ideas about what to write although their writings were still lacked of details and supporting information. Then secondly dealing with the organization, the students have increased their ability to produce a well-organized and cohesive text. The idea were stated and supported. The students started to be able to organize the ideas based on the generic structure of the text although it was still in a simple way.

Thirdly dealing with the vocabulary, the students started to be able to use correct and appropriate words. However, it is still difficult for many students to make it flawless. Sometimes, they still asked the teacher because they were reluctant to bring or to open the dictionary. The important thing is that their vocabulary mastery has improved. Fourthly dealing with the language use, many students were able to distinguish nouns, verbs and adjectives. They also had been able to use to be (Is, Am, Are) properly. However, they still lack of using the simple present correctly. Lastly dealing with mechanic, the students began to pay attention to the punctuation but sometimes wrongly used the capitalization. Sometimes, they still misspelled the words as well. 
Some of them ignored paragraphing. Again, many students still found it difficult to correct all of their errors by themselves. In this case the researcher and the collaborator helped them to be aware of the errors they had done and corrected them together.

\subsection{Cycle II}

In the post test of Cycle II, the improvement in teaching descriptive texts through mind mapping had been clearly seen. It was showed by students' score based on the rubric. The students have clearly improved in terms of five aspects. Firstly dealing with the content, the students were able to develop their writing adequately and relevant to the topic. The students could develop the idea into more complex one. They started to add some supported information in their writing. Then secondly dealing with the organization, the students were able to produce and to enhance a wellorganized and cohesive text. Their writings were well written and well read. The idea were clearly sated and supported.

Thirdly dealing with the vocabulary, the students were able to use correct and appropriate words. Students' mastery of vocabulary had obviously improved. They were accustomed to open the dictionary to find words. Sometimes, they discussed with friends in choosing the appropriate words. Fourthly dealing with the language use, many students were able to distinguish nouns, verbs and adjectives. They also had been able to use to be (Is, Am, Are) properly. In addition, they were able to use the simple present tense appropriately. Lastly dealing with mechanic, the students were able to use correct punctuation and capitalization well. They got used to put full stop in the end of sentences. Then, they were able to use capital letters appropriately. They always paid attention to the spelling of the words. Therefore, it was obvious that mind mapping is an accurate way to teach them English especially writing descriptive texts.

\subsection{Students' Score}

This part presents the discussion of the results of the students' score from the pre-test, the posttest of Cycle I and Cycle II. The following tables show the mean score in five aspects according to the rubric. It can be seen below:

Table 1: The Mean Score in Five Aspects According to the Rubric

\begin{tabular}{|l|l|l|l|}
\hline Criteria & Pre-test & Post-test Cycle1 & Post-test Cycle 2 \\
\hline Content & 2.442 & 2.930 & 3.512 \\
\hline Organization & 2.512 & 3.023 & 3.116 \\
\hline Vocabulary & 2.395 & 2.744 & 3.093 \\
\hline Language Use & 2.372 & 2.791 & 3.116 \\
\hline Mechanic & 2.395 & 2.721 & 3.163 \\
\hline
\end{tabular}

\section{Content Aspect}

The table above shows the mean score of the content aspect increased after the action during the implementation of mind mapping. The gain score is 0.488 from the post-test of Cycle I and becomes 2.930 after conducting the post-test of Cycle II. The gain score is 0.222. 


\section{Organization Aspect}

In the organization aspect, the students have improved in Cycle I and the gain score is 0.349. After conducting the post-test of Cycle II, the mean score becomes 3.023. Thus the gain score is 0.093 .

\section{Vocabulary Aspect}

In the vocabulary aspect, the students also make some improvements. In the pre-test, the mean score is 2.395. After doing the action in the post- test of Cycle I, the mean score improves into 2.744. Then, it continues improving in the post-test of Cycle II. It becomes 3.093. The gain score obtained is 0.349 .

\section{Language Use Aspect}

The result of the mean score in the language use aspect presented in the table also shows a significant improvement. In the pre-test, the mean score is 2.372. It improves in the post-test of Cycle I in which the mean score is 2.791 . Then, the mean score after conducting the posttest of Cycle II is 3.116 .

\section{Mechanic Aspect}

The table above presents the mean score in the mechanic aspect. The gain score of the post-test of Cycle I is 0.326. Then, after conducting the post-test of Cycle II, the mean score becomes 3.163. So the gain score is 0.442 .

The overall improvements achieved by the students of the first grade of SMAN 4 Kota Kupang are presented in the chart below:

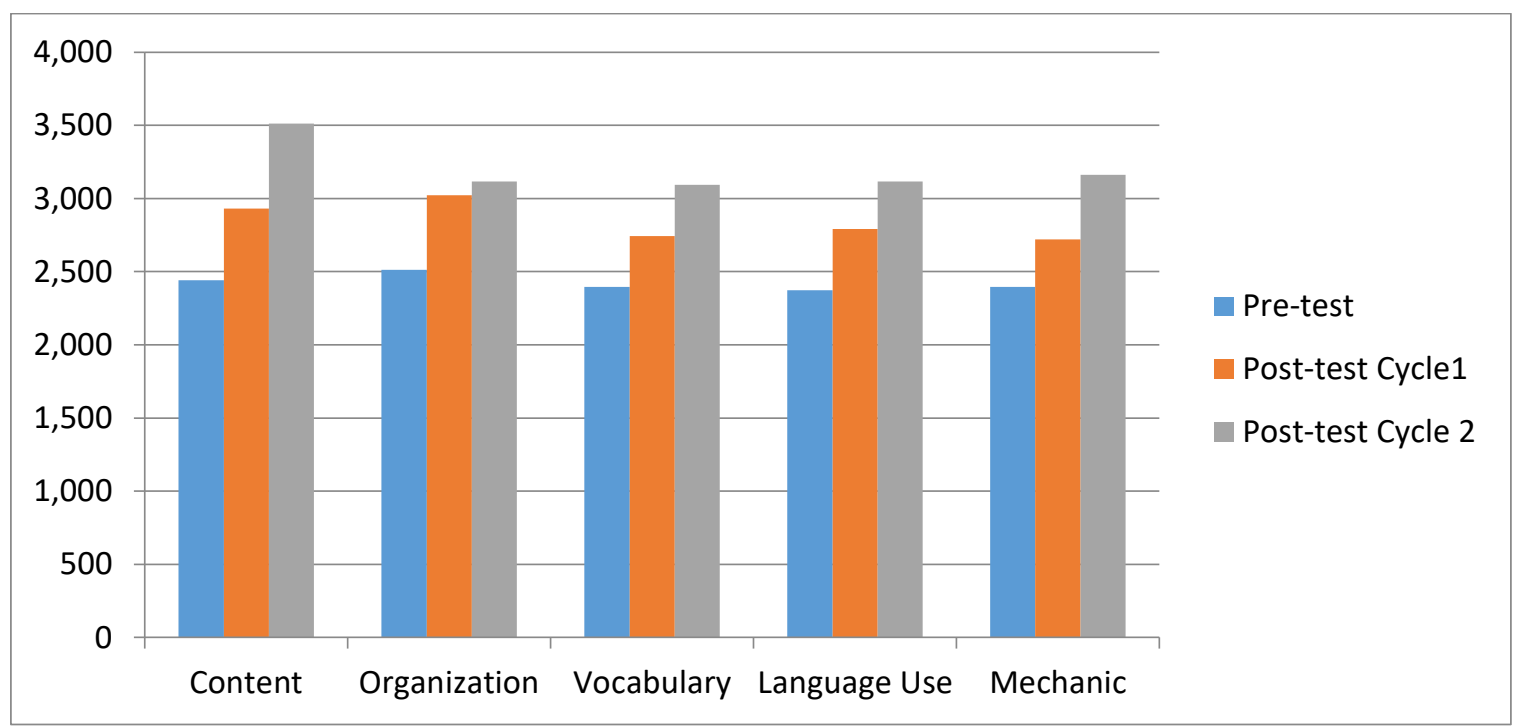

Figure 1: The Students' Improvement Based on the Rubric in Five Aspects

In reference to the discussion above, the students' writing ability improved in five aspects of writing which are content, organization, vocabulary, language use and mechanics. Here, the researcher also presents the general findings of the students' scores in five aspects of writing from pre-test, post-test cycle 1 and post-test cycle 2 as follows. 
Table 2: General Findings of the Students' Score from Pre-test, Post-test cycle 1 and Post-est cycle 2

\begin{tabular}{|l|l|l|l|}
\hline Component & Pre-Test & Post-test cycle 1 & Post-est cycle 2 \\
\hline Mean Score & 60.58 & 70.81 & 78.60 \\
\hline
\end{tabular}

The scores are obtained from the accumulation of the students' scores in all five aspects of writing in pre-test, post-test cycle 1 and post-test cycle 2 . In the pre-test, the mean score is 60.58 . It increases into 70.81 in post test cycle1. In post test cycle 2 , the mean score is 78.60 . The following chart shows obvious improvements made by the students.

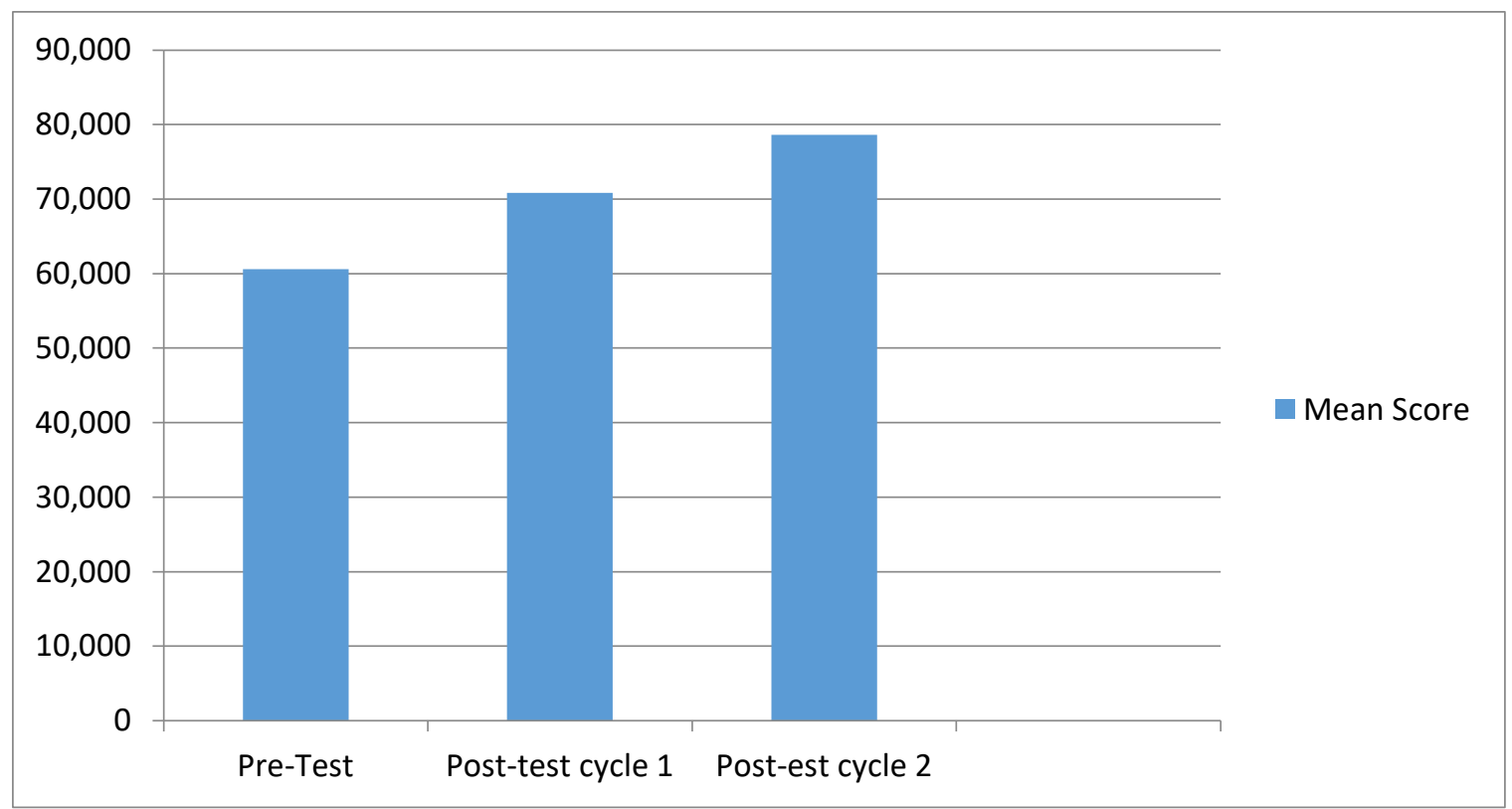

Figure 2: General Findings of the Students' Score from Pre-test, Post test Cycle1, and Post test Cycle 2

From the explanation above, it can be concluded that the use of mind mapping can improved the writing ability of the tenth grade students of SMA Negeri 4 Kupang.

\section{Conclusion}

The writer can be concluded that the mind mapping teaching straegy improved the students writing ability. The students able to use the appropriate vocabulary, correct grammar, punctuation, spelling, and capitalization in their writings. During the teaching and learning process, they also showed positive response toward the lesson. They enthusiastically joined the teaching and learning activities and did the tasks well. The improvement of the students' writing skill also can be seen from the result of mean score in pre-test and post-test 1 and 2. The improvement involves the students' ability in contents, language use, vocabulary, organization, and mechanic. The improvement could be showed from the students' achievement score. In the pre-test, the mean score is 60.58. It increases into 70.81 in post test cycle1. In post test cycle 2 , the mean score is 78.60 . 


\section{Reference}

[1] Adelstein, Michael E. And Jean G. Pival, (1984). The Writing Commitment ( $3^{\text {rd }}$ ed), San Diego: Garcourt Brace Jovanovich

[2] Anderson, Mark and Kathy Anderson, (1997). Text types in English 1, South Yarra : Macmilan

[3] Arikunto, Suharsimi (2009). Penelitian Tindakan Kelas, Jakarta : Bumi Aksara

[4] Barnet, Sylan and Marcia Stubbs, Barnet and Stubbs's (1983) Practical Guide to Writing, Boston: Little, Brown and Company

[5] Burns, Anne (2010). Doing Action Research inLanguage Teaching : A guide for practitioners. Ny.Routledge. Pp. 196

[6] Braine, George and Claire May (1996). Writing from Sources: A guide for ESL Students, California : Mayfield

[7] Boardman, C. Fridenburg J. (2002). Writing to CommunicateI. New York: Longman

[8] Brown, H. Douglas (2001). Teaching by Principles : An Interactive Approach to Language Pedagogy $\left(2^{\text {nd }} \mathrm{ed}\right)$. New York: Addison Wesley Longman.

[9] Brown, James Dean (2005). Testing in language programs: A Comprehensive Guide to English Language Assesment, New York: McGraw-Hill

[10] Buzan, Tony (2006). Buku Pintar Mind Map, Jakarta: Gramedia Pustaka Utama.

[11] Buzan, Tony (2010). Buku Pintar Mind Map untuk anak, Jakarta : Gramedia Pustaka Utama

[12] Gerhard, Jerry G (2006). Teaching English as Foreign or Second Language (2 ${ }^{\text {nd }}$ ed), Michigan: The University of Michigan

[13] Heaton, JB (1998). Writing English Language, New York

[14] Hoshima, Alice and Ann Hogue (2007). Introduction to Academic Writing ( $3^{\text {rd }}$ ed), New York: Pearson Education

[15] Kollin, C. Philip (2008). Succesful Writing at Work. Second Edition. United States of America: Houghton Mifflin Harcount Publishing Company

[16] Mills, Geoffrey E (2003). Action Research: A Guide for the Teacher Research, Ohio: Merrill Prentice Hall.

[17] Nunan, D. (2003). Practical English Language Teaching, New York: The McGraw-Hill companies

[18] Oshima, A and Hogue, A (2007) Introduction to academic writing. New York: Person education, Inc

[19] Pharr, Donald and Santi Buscemi (2005). Writing Today : Context and options for the Real World, Boston: McGraw-Hill.

[20] Richards, Jack C and Willy A. Renandya (2002) Methodology in Language Teaching : ontology of Currect Practice, New York: Cambridge University. Press.

*Corresponding author.

E-mail address: frangelinapajoliasalem@ gmail.com 